\title{
Issues surrounding the Rregistration of a Single Colour as a
} Trade Mark

\section{Asst. Lecturer: Govan Tahseen Shukri}

College of Law and Political Sciences / Salahaddin University-Erbil

\section{ARTICLE INFO}

\section{Article History:}

Received:26/7/2018

Accepted: 23/9/2018

Published: Fall 2018

Doi:

10.25212/lfu.qzj.3.4.31

Keywords:

Trademark, company

Registration,

requirement

Protection, granting

single colour

Iraqi law, the Kurdistan

Region, service

goods

\section{ABSTRACT}

Trade marks play a key role in trading since the customer is able to differentiate the goods and services of one company from the ones of another through the trademark which is usually put on the product or the service. Traditional trademarks are, somehow, easier to be protected by way of registration. However, there are now nontraditional trade marks (particularly a colour per se) that might not enjoy protection due the fact that the registration requirements of such marks may not be easily satisfied on the one hand; and, on the other hand, granting protection to a single colour for example might be very counterproductive and hinder competition. This paper, therefore, critically analyses the issues facing the registration of a single colour as a trade mark and the possibility of such registration under the Iraqi law. It also elaborates the issues that may face traders in the Kurdistan Region and Iraq in case they intend to register a single colour as a badge of origin for their goods and services. 


\section{QALAAI ZANIST SCIENTIFIC JOURNAL \\ A Scientific Quarterly Refereed Journal Issued by Lebanese French University - Erbil, Kurdistan, Iraq \\ Vol. ( 3 ), Issue ( 4 ), Fall 2018 \\ ISSN 2518-6566 (Online) - ISSN 2518-6558 (Print)}

LF U

The idea of trade marking has ancient history which stretches back to Egyptian structures; also in Greek and Roman times, signs put on pottery were used as an indicator that they belong to their owners. ${ }^{1}$ Thus, these signs have shown throughout history that they are badge of origin and they have also shown the quality of the product associated. ${ }^{2}$ Then, this idea has developed and become the issue which needs to be regulated. Hence, trade marks have been regulated by law and they are, as other IP rights, property rights.

Despite the fact that they are regulated, they have become problematic and subject to a number of cases before the courts; this may be due to new technological developments that raise a number of questions about the ambit of trade marks; the issue of unduly monopolising a sign, in particular in colour, and how different interests would be balanced. ${ }^{3}$

This paper, therefore, aims to discuss the title question by addressing first, requirements for a single colour so as to be trademarked and two types of distinctiveness are examined in detail. Then, arguments are made about the question of whether the registration of a single colour is counterproductive, and finally, how the balance between acquiring distinctiveness through use and leaving colour free for others (free competition) could be kept. This is mainly by reference to case law, the Trade Marks Directive and the UK Trade Marks Act 1994; it also touches upon relevant US cases and decisions; and, at the end, it will explain whether registration of a single colour as a trade mark is possible under Iraqi law and the issues facing it? But before going into a deep discussion, the paper starts with an overview.

\section{An Overview}

Trade marks would be, in general, divided into two main groups; traditional and non-traditional ones. The former may include words, letters, numerals, designs or the shape of goods or their packaging; the latter, on the other hand, may include: olfactory, scent, sounds or colours. Thus, colour marks have been trade marks and the most successful non-traditional marks, regarding

\footnotetext{
${ }^{1}$ Anson Obayuwana, 'Unintentional trademark expansion and unfair competition in cyberspace: the domain name phenomenon' (2012) 34(3) EIPR 177.

2 Paul Torremans, Holyak and Torremans intellectual property law ( $6^{\text {th }}$ edn, OUP 2010) 385.

3 Jekaterina Kudrjavceva, 'Issues surrounding registration of colour trade marks' (2012) 09 Riga Graduate School of Law research paper 12.
} 


\section{QALAAI ZANIST SCIENTIFIC JOURNAL \\ A Scientific Quarterly Refereed Journal Issued by Lebanese French University - Erbil, Kurdistan, Iraq \\ Vol. ( 3 ), Issue ( 4 ), Fall 2018 \\ ISSN 2518-6566 (Online) - ISSN 2518-6558 (Print)}

LFU

the number of marks registered. ${ }^{4}$ Colours, as trade marks, have been used for over 15 years. ${ }^{5}$ It was first granted registration in the US by the Supreme Court when the Court decided in Qualitex ${ }^{6}$ case.

In the EU, the courts have started interpreting the law as it covers colours as trade marks. Although in its member states the issue has become the case in several instances: started with Germany in $1998,{ }^{7}$ in the same year, in Orange Personal Communication ${ }^{8}$ case, the OHIM Board of Appeal affirmed that colour per se may be protected although the application for registering a colour orange was refused. In 2002, the General Court dismissed the application of the shade orange for agricultural products and seed treatment was dismissed as it was not represented by any colour code since different colours (from dark to light and from yellowish to reddish) can all be seen under the wide notion of 'orange' but it was held that a colour might be protected as a mark. ${ }^{9}$

In 2003 and for the first time, the ECJ, in Libertel, ${ }^{10}$ was asked whether a single colour can be a trade mark. Although the colour orange was rejected to be a trade mark in this case, the Court made it clear that colours even a single one may be registered as trade marks. Indeed, in Nestle v. Cadbury, ${ }^{11}$ the single colour-purple-was successfully registered. The case was the UK IPO case concerned the registration of the colour purple (Pantone 2685C) for chocolate products; hence, after amendments made in the application, the colour was accepted to be a trade mark applied for the whole or predominantly to the visible surface of the chocolate's packaging in bar and tablet form and drinking chocolate. ${ }^{12}$

Colour marks as any other trade mark can enjoy protection and its proprietor will be granted exclusive rights, as any other IP right, which will preclude others from using it. However, it is important to know whether there

\footnotetext{
${ }^{4}$ Office for the Harmonization in the Internal Market, CTM statistics on 03/04/2012, SSC009 p. $47<$ http://oami.europa.eu/ows/rw/resource/documents/OHIM/statistics/ssc009statistics of community trade marks 2012.pdf> accessed 18 July 2018.

${ }^{5}$ Kudrjavceva (n 3) 12.

${ }^{6}$ Qualitex Co. v. Jacobson Prods. Co. case [1995] 514 US 159.

7 Farbmarke Gelb-Schwarz, BGH GRUR 491, 30 IIC 809 (1999).

8 Third Board of Appeal's decision [12 February 1998], Case $R$ 7/97-3.

${ }^{9}$ Case T-173/00 KWS Saat AG v (OHIM) [2002] ECR II-3847, para. 25.

${ }^{10}$ Case C-104/01 Libertel Groep BV v Benelux-Merkenbureau [2003] I-3793.

${ }^{11}$ Societe des Produits Nestle SA v Cadbury UK Ltd [2012] EWHC 2637 (Ch); [2013] E.T.M.R. 2 (Ch D). 12 ibid.
} 


\section{QALAAI ZANIST SCIENTIFIC JOURNAL \\ A Scientific Quarterly Refereed Journal Issued by Lebanese French University - Erbil, Kurdistan, Iraq \\ Vol. ( 3 ), Issue ( 4 ), Fall 2018 \\ ISSN 2518-6566 (Online) - ISSN 2518-6558 (Print)}

LFU

are, if any, extra requirements for colour per se to be protected. Therefore, the requirements are explained below.

A trade mark has been defined under different regimes and systems. The TRIPS $^{13}$ Agreement, which is applicable to all WTO ${ }^{14}$ members, in Article 15(1) defines a trade mark. ${ }^{15}$ Further, in the EU it has also been defined by the Trade Marks Directive ${ }^{16}$ as 'any signs capable of being represented graphically........capable of distinguishing the goods or services of one undertaking from those of other undertakings. ${ }^{17}$ As a result, Council Regulation $(E C)^{18}$ on the Community trade mark (CTMR) also comes and defines a trademark, under Article 4 of the CTM in the exact wording akin to that of the Directive. Thus, in the UK, the 1994 Act, has also the same definition for a trade mark. ${ }^{19}$

From the above-mentioned definitions of a trade mark, it can be noted that there are, in general, three requirements which must be satisfied in order for any mark, including colour per se to be registered. They are now explained but only regarding colour marks.

\section{Requirements for Registration a Trade Mark}

First, a colour mark must be a sign as any other trade mark. It is clearly mentioned that signs which cannot constitute a trade mark must not be registered and if registered, the registration will be invalid. ${ }^{20}$ The purpose, as

${ }^{13}$ Agreement on Trade-Related Aspects of Intellectual Property Rights (1994).

${ }^{14}$ The World Trade Organisation.

${ }^{15}$ TRIPS Agreement, Art. 15(1): 'any sign, or any combination of signs, capable of distinguishing the goods or services of one undertaking from those of other undertakings, shall be capable of constituting a trademark. Such signs, in particular words including personal names, letters, numerals, figurative elements and combinations of colours as well as any combination of such signs, shall be eligible for registration as trademarks." <https://www.wto.org/english/docs e/legal e/27-trips 04 e.htm> accessed 9 July 2018

16 Directive 2008/95/EC of 22 October 2008 to approximate the laws of the Member States relating to trade marks [2008] L 299/25.

17 The Trade Marks Directive, Art. 2: 'A trade mark may consist of any signs capable of being represented graphically, particularly words, including personal names, designs, letters, numerals, the shape of goods or of their packaging, provided that such signs are capable of distinguishing the goods or services of one undertaking from those of other undertakings'.

${ }^{18}$ Council Regulation (EC) No 207/2009 of 26 February 2009 on the Community trade mark [2009] L78/1.

19 Trade Marks 1994 Act, S. 1(1).

20 Trade Marks Directive, Art. 3(1)(a). 


\section{QALAAI ZANIST SCIENTIFIC JOURNAL \\ A Scientific Quarterly Refereed Journal Issued by Lebanese French University - Erbil, Kurdistan, Iraq \\ Vol. ( 3 ), Issue ( 4 ), Fall 2018 \\ ISSN 2518-6566 (Online) - ISSN 2518-6558 (Print)}

LFU

mentioned in Dyson ${ }^{21}$ case, is to avoid the abuse of trade mark law and preventing a trade mark from being granted unduly. It is notable under all abovementioned regimes including, Article 2 of the Trade Mark Directive, colour per se is not expressly mentioned. However, it has been evident that the list of the signs mentioned there is not exhaustive and it represents merely some examples; ${ }^{22}$ hence, a sign is 'anything which can convey information'. ${ }^{23}$ Consequently, it would be said that a colour as a sign can constitute a mark as long as it meets conditions required by the Directive-that is, no further conditions should be required. ${ }^{24}$

It was further clarified that an abstract concept is not a sign but a sign will be any message recognised by the five senses. ${ }^{25}$ In Liberte $^{26}$ case, it was held that although colour is a property of things, it is incapable of being a sign under the Directive. It seems therefore that a colour can constitute a sign. The recent acknowledgement has been Nestle v. Cadbury $^{27}$ case: the argument (a colour purple could take many forms of appearance and thus is not a sign) was rejected; and it was held that the colour purple is fixed and stable.

Secondly, a sign is to be represented graphically. In Liberte ${ }^{28}$ case and for the first time, the issue of a single colour was put before the ECJ whether it can be a mark. The Court applied criteria established in the Sieckmann ${ }^{29}$ case, and found that the application of colour orange, regarding graphical representation did not meet all requirements: it must be clear, self-contained, precise, durable, easily accessible, intelligible and objective. Thus, it was held that orange per se is not durable enough since it may fade easily, it may also change depending on

${ }^{21}$ Case C-321/03 Dyson Ltd. v. Registrar of Trade Marks [2007] ECR I-687, [2007] 2 CMLR 14, [2007] RPC 27.

${ }^{22}$ Case C-273/00 Ralf Sieckmann v Deutsches Patent- und Markenamt ('Methylcinnamat') [2002] ECR I-11737, para. 44; see also Trade Marks Directive, preamble, recital 8.

23 Philips Electronic BV v. Remington Consumer Products [1998] RPC 283, Jacob J, cited in Torremans (n 2) 392.

${ }^{24}$ Case C-299/99 Koninklijke Philips Electronics v Remington Consumer Products Ltd. [2002] ECR I-5475, para. 32.

${ }^{25}$ Case C-321/03 Dyson Ltd. v. Registrar of Trade Marks [2007] ECR I-687, [2007] 2 CMLR 14.

${ }^{26}$ Case C-104/01 Libertel Groep BV v Benelux-Merkenbureau [2003] I-3793.

27 Societe des Produits Nestle SA v Cadbury UK Ltd [2012] EWHC 2637 (Ch); [2013] E.T.M.R. 2 (Ch D).

${ }^{28}$ Case C-104/01 Libertel Groep BV v Benelux-Merkenbureau [2003] I-3793 [2004] ECR II-3843.

${ }^{29}$ Case C-273/00 Ralf Sieckmann v Deutsches Patent- und Markenamt ('Methylcinnamat'), [2002] ECR I-11737. 


\section{QALAAI ZANIST SCIENTIFIC JOURNAL \\ A Scientific Quarterly Refereed Journal Issued by Lebanese French University - Erbil, Kurdistan, Iraq \\ Vol. ( 3 ), Issue ( 4 ), Fall 2018 \\ ISSN 2518-6566 (Online) - ISSN 2518-6558 (Print)}

LF U

the background on which it is applied. ${ }^{30}$ However, the colour orange might have passed the test if there was a combination of verbal description and a sample; also it would have been possible if internationally standard colour codes were used. ${ }^{31}$

However, the court, in Libertel case, did not close the door upon a single colour from being trademarked as stated that 'the possibility that colour per se may in some circumstances serve as a badge of origin'. ${ }^{32}$ Indeed, it has been successfully accepted to be a badge of origin as a trademark. In Nestle v. Cadbury, ${ }^{33}$ purple shade per se satisfied the requirements set out in Sieckmann case. It was further found by the hearing officer that the colour has been graphically represented as there is no combination of colours and other materials are not to be deemed as part of the sign; thus, it was a single colour.

Further, it was claimed not to be objective because of the word 'predominant' but it was found that the word in question did not lead to further vagueness, and was acceptable. It was further claimed that the colour is not certain but it was refused since the colour is predominantly used, and the wording and description did not offer any alternative - that is, it is certain and precise. ${ }^{34}$ Thus, it was held that the colour has met all Sieckmann requirementsthat is, it is graphically represented.

The third requirement is that a sign must be distinctiveness. ${ }^{35}$ This is the most difficult requirement to be met by colour marks; they are often found that are not adequately distinctive to be deemed a property of one trader even if they are compared to other non-traditional trade marks. ${ }^{36}$ Hence, by analogy, it is the same for a single colour. Distinctiveness means conveying a message which shows the source, responsibility and quality of products labelled with the mark: this is the principal purpose of a trade mark. ${ }^{37}$

${ }^{30}$ Case C-104/01 Libertel Groep BV v Benelux-Merkenbureau [2003] I-3793 [2004] ECR II-3843.

31 Torremans (n 2) 396.

${ }^{32}$ Case C-104/01 Libertel Groep BV v Benelux-Merkenbureau [2003] I-3793 [2004] FSR 65, para 41.

${ }^{33}$ Societe des Produits Nestle SA v Cadbury UK Ltd [2012] EWHC 2637 (Ch); [2013] E.T.M.R. 2 (Ch D).

34 ibid.

${ }^{35}$ Trade Marks Directive, Art. 2 supported by Art. 3(1)(b): 'trade marks which are devoid of any distinctive character'.

36 David I. Bainbridge, 'Smell, sound, colour and shape trade marks: an unhappy flirtation?' (2004) JBL 219.

37 Glaxo Group v. Dowelhurst Ltd [2004] FSR 529, cited in Torremans (n 2) 397. 
There have been several attempts to register a single colour mark (a number of them for colours as combination) but they have been rejected due to the lack of this requirement. For instance, in Libertel the abstract orange colour mark was rejected since it did not comply with the general rule which has been consistently used in several cases. The rule is that in order to assess distinctiveness test, the focus must be first on 'the goods or services in respect of which registration is sought'; secondly, 'the perception of the relevant consumers', ${ }^{38}$ as whether the consumers will see a mark distinguishing the goods or services of one undertaking from those of other ones. ${ }^{39}$

As far as possessing distinctiveness is concerned, it is admitted that there are two types of distinctiveness - either inherent or acquired. Regarding a single colour, the former is very difficult, if not impossible, to be possessed, and evidence will usually be required. ${ }^{40}$ As was seen in Libertel, an abstract colour could not inherently distinguish the goods of one source from those of another but it may be capable of doing so when the relevant market is very specific and the number of goods or services is very limited. ${ }^{41}$ In Orange case, it was also confirmed that only a certain or limited colour shades may be inherently distinctive but for very specific goods or services..$^{42}$ It appears that the most often one will be acquired distinctiveness through use by 'the process of familiarising the relevant public'. ${ }^{43}$

As can be seen that Article 3(3) of the Trade Marks Directive states that a trade mark will be registered and valid (it will be under $1 \mathrm{~b}, \mathrm{c}$ or $\mathrm{d}$ ) if before the date of application, it has acquired a distinctive character. In Cadbury case, the colour purple has been registered due to acquiring distinctiveness through use and it was shown that the purple for chocolate has been used for about 100 years. Moreover, Cadbury Ltd is a famous company in this regard; the companies advertising and its marketing strategies; the amount of investment and

${ }^{38}$ Case C-404/02 Nicholas PLC v. Registrar of Trade Marks [2004] ECR I-8499.

39 Torremans (n 2) 398.

40 AIPPI, Report of the UK Group, Q 181: Mutimear, Vowinckel and Abnett, 'Conditions for registration and scope of protection of non-conventional trademarks' (Q 11) <http://www.aippi.org.uk/docs/Q181.UK\%20Group.Response.pdf> accessed 20 June 2018.

${ }^{41}$ Case C-104/01 Libertel Groep BV v Benelux-Merkenbureau [2003] I-3793 [2004] ECR II-3843, para 65.

42 Third Board of Appeal's decision [12 February 1998] in (Orange Case) para 16.

${ }^{43}$ Case C-104/01 Libertel Groep BV v Benelux-Merkenbureau [2003] I-3793 [2004] ECR II-3843, para 67. 


\section{QALAAI ZANIST SCIENTIFIC JOURNAL \\ A Scientific Quarterly Refereed Journal Issued by Lebanese French University - Erbil, Kurdistan, Iraq \\ Vol. ( 3 ), Issue ( 4 ), Fall 2018 \\ ISSN 2518-6566 (Online) - ISSN 2518-6558 (Print)}

LFU

consistency in using the colour; all these were taken into account. ${ }^{44}$ Although Nestle argued that there are other companies using purple, it was decided that the law does not require being the only user of a colour. ${ }^{45}$ Therefore, without any spatial delimitation, a colour was registered since it was clearly defined and it is used as badge of origin; the relevant public can distinguish the colour purple of Cadbury chocolate and drinks from those of others. Consequently, it acquired distinctiveness. ${ }^{46}$

In essence, trade marks are pro-competitive since they enable the origin of goods to be distinguished. ${ }^{47}$ However, it is controversial whether a single colour as a trade mark stimulates competition. It would be said that colour marks would fulfil the same functions as other trade marks do but a single colour will result in certain issues which eventually may inhibit competition. Although this issue has recently been settled in Cadbury case by granting purple protection, it raises more questions than answers. Therefore a number of arguments could be made for and against whether Cadbury case (a single colour purple) is counterproductive. Therefore, they are addressed below.

BP $\mathrm{Amco}^{48}$ case also acquired distinctiveness through use. A final point which should be made is that, a single colour akin to other trade marks must fulfil the requirements mentioned so as to be registered without any further conditions. The most controversial way of protecting colours is registering a single colour, ${ }^{49}$ as a trade mark. This tendency started when colour purple in Cadbury case became a trade mark. The issue of whether registering colour per se will inhibit rather stimulate competition will be discussed.

${ }^{44}$ Case 0-358-11 of 20 October 2011, Application no 2376879 by Cadbury Ltd and Opposition 97819 by Societe des Produits Nestlé S.A, see paras: 1, 9, 13, 103, 104, 16 and $111<$ http://www.ipo.gov.uk/types/tm/t-os/t-find/t-challenge-decisionresults/035811.pdf> accessed 17 May 2018.

${ }^{45}$ Societe des Produits Nestle SA v Cadbury UK Ltd [2012] EWHC 2637 (Ch); [2013] ETMR 2 (Ch D).

${ }^{46}$ Ian Wood and Mary Bagnall, 'Colour marks: a purple decision clears the way forward' (2013) 35(5) EIPR 300.

47 Torremans (n 2) 389.

${ }^{48}$ BP Amoco plc $v$ John Kelly Ltd [2002] FSR 4 and 5: BP Amco, which is the owner of green mark for the petrol stations, brought proceeding against the defendant since the same colour was used; the Northern Ireland Court decided that the colour green is acquired through use as a well-known brand and trade mark; the public recognises it through its colour.

${ }^{49}$ Charlotte Schulze, 'Registering colour trade marks in the European Union' (2003) 25(2) EIPR 55. 


\section{QALAAI ZANIST SCIENTIFIC JOURNAL \\ A Scientific Quarterly Refereed Journal Issued by Lebanese French University - Erbil, Kurdistan, Iraq \\ Vol. ( 3 ), Issue ( 4 ), Fall 2018 \\ ISSN 2518-6566 (Online) - ISSN 2518-6558 (Print)}

LFU

\section{A Single Colour Inhibits not Stimulates Competition}

As mentioned above, trade marks, in general, are pro-competitive yet it is questionable whether registering a single colour serves this objective. It has been settled that colour per se can serve as a trade mark after satisfying all requirements. However, in order to protect free competition, deeming colour per se as a trade mark should be restricted..$^{50}$

Issues will arise with colour per se as a trade mark since a registered trade mark grants its proprietor exclusive rights that will prevent others from using similar but confusingly or identical signs in the business. ${ }^{51}$ Further, it is argued that due to the fact that a colour has a special nature which is not confined by any logotype or shape; consequently, the rights of its proprietor might be unduly extended. Thus, colour per se in order for it to acquire distinctiveness, there is a higher-in some states-threshold, Germany for example. ${ }^{52}$ Moreover, in Canada for instance, colour per se cannot be registered as a trade mark since it is deemed that it would be monopolised by one industry forever. ${ }^{53}$ As a result, commentators have taken different views about this issue and its link with competition. Therefore, these arguments are discussed below.

As far as the use of colour is concerned, it is inevitable since colour is generally used for logotype, packaging, containers and advertising as well. If it is given to one trader, the registered colour mark will grant its proprietor rights which could interfere with rights of other traders and will preclude them from those uses. ${ }^{54}$ Further, colour can attract consumers' attention and it plays a prime role when purchasers choose to buy the product; therefore, they are not only inevitable, but also helpful and beneficial. As a result of that, colour can lead people to like one particular item, due to colour it has, more than others, and even people may choose a product to buy since they are attracted by a colour. ${ }^{55}$

50 Kudrjavceva (n 3) 36.

51 Trade Marks Directive, Art. 9(1).

52 Maria Cristina Caldarola, 'Questions relating to abstract colour trade marks: recent developments in

Germany' (2003) 25(6) EIPR 248.

53 Kudrjavceva (n 3) 37.

54 Bainbridge (n 36) 219.

55 Sunila Sreepada, 'The New Black: Trademark Protection for Color Marks in the Fashion Industry' (2009) 19(4) Fordham Intellectual property, Media and Entertainment Law Journal 1131. 


\section{QALAAI ZANIST SCIENTIFIC JOURNAL \\ A Scientific Quarterly Refereed Journal Issued by Lebanese French University - Erbil, Kurdistan, Iraq \\ Vol. ( 3 ), Issue ( 4 ), Fall 2018 \\ ISSN 2518-6566 (Online) - ISSN 2518-6558 (Print)}

LF U

It is evident that sometimes an industry may lack of a desirable colour. Thus, new traders will find themselves in such an aggrieved position if there are all attractive colours already used and less attractive colours will be chosen for future businesses. ${ }^{56}$ It should be remembered that colour is capable of individualising the goods and services of a particular business through its most important quality which is obtaining protection as a trade mark, ${ }^{57}$ and it can elevate brand recognition by up to 80 percent. $^{58}$

The above-mentioned arguments show that there is a denial of availability of colour to other rival traders and they cannot obtain the same colour since it has become a trade mark; thus objections to monopolisation of such colours will be logically accepted although they may exceed their extent. ${ }^{59}$

Moreover, arguments made concern about the issue of limited availability of colours exist. This is known as 'colour depletion theory', and their advocators concern about the issue that there are a limited number of colours and of they are all used, there will be no competition because the new rival business cannot use those colours. ${ }^{60}$ Although it is said that there are a number of colours and their shades are plenty-that is, they can be used and without having a monopolisation, this argument may not go too far since distinguishing all these colours, remembering and associating them by the relevant public or average purchasers is restricted. ${ }^{61}$

This theory has been admitted in a number of cases. In Libertel, although it was established that a colour can be a trade mark, the court also concerned about the fact that there is a limited number of colours which can be distinguished by public, and it is rare for the public to compare products directly when variety of shades have been used-that is, the relevant public is not capable of distinguishing a large number of colours used. ${ }^{62}$

\footnotetext{
${ }^{56}$ Kudrjavceva (n 3) 39.

57 UK IPO Trade Mark Manual, <http://www.ipo.gov.uk/tmmanual-chap3-exam.pdf> accessed 02 June 2018.

58 Jill Morton, 'Why Colour Matters' (2010) <http://www.colorcom.com/research/why-colormatters > accessed 25 July 2018; see also other features that colour has and they play role in marketing.

59 Kudrjavceva (n 3) 40.

${ }^{60}$ See Qualitex Co. v. Jacobson Prods. Co. case [1995] 514 US 159.

${ }^{61}$ Schulze (n 49) 55.

62 Case C-104/01 Libertel Groep BV v Benelux-Merkenbureau [2003] I-3793 [2004] ECR II-3843, para 47.
} 


\section{QALAAI ZANIST SCIENTIFIC JOURNAL \\ A Scientific Quarterly Refereed Journal Issued by Lebanese French University - Erbil, Kurdistan, Iraq \\ Vol. ( 3 ), Issue ( 4 ), Fall 2018 \\ ISSN 2518-6566 (Online) - ISSN 2518-6558 (Print)}

LFU

It was also the concern in William Wrigley Junior ${ }^{63}$ case, when it was stated that accepting basic and compound colours as a trade mark could prevent those who may wish to sue colour for various reasons in connection with their products. This is because of 'the limited nature of colours spectrum'; hence, depriving market of its diversity of colours cannot be the aim of a trade mark. ${ }^{64}$ It can therefore be said that even if colours or shades are plenty and available, consumers may not be able to distinguish all. As a result of that, they might be confused and variety of colours may lead them not to buying those products. Furthermore, it is argued that colours are not used alone, rather they are combined with textual marks - that is, they are playing supporting or secondary role and should not be registered since it is textual marks give certainty not a colour. If they are allowed to be trademarked, it is simply wrong since they are usually aesthetically functional. ${ }^{65}$

Additionally, in IKEA ${ }^{66}$ case, one of the reasons of refusing blue-yellow colour was that the colours in question were not sufficiently different from the 'basic' or 'primary' colours; hence, an imperfect memory of the shades will remain in purchasers' mind. Similarly, in Light Green ${ }^{67}$ case, regarding chewing gums as it was found that light green as colour per se is usually used in fashion and is not 'exceptionally unique or unusual'. It seems therefore that colour per se in order for it to be deemed as a trade mark, it is to be unusual and unique; it could be said that colour purple shade is used in Cadbury case was exceptionally unique and not commonly used in business.

Apparently, the idea of refusing the registration of a single colour stems from the attempt that unduly monopolisation granted should be avoided in order not to place competitors at a disadvantageous position which would be easy in cases of colour per se. ${ }^{68}$ If this approach is followed, competition could preclude less attractive shades from being registered as trade marks. The approach in question can be seen in the UK that if a colour is a basic or a shade

63 Decision of the Third Board of Appeal of [18 December 2000] in Case R 122/1998-3 (Light Green).

64 ibid para 30.

${ }^{65}$ Ann Bartow, 'the True Colors of Trademark Law: Green lighting a Red Tide of Anti Competition Blues' (2009) 207 Kentucky Law Journal 263.

${ }^{66}$ Decision of the First Board of Appeal, [1 July 2005] in Case $R$ 799/2004-1 (IKEA, Blue and Yellow) para 20.

67 ibid para 24.

68 Sreepada (n 55) 1131. 


\section{QALAAI ZANIST SCIENTIFIC JOURNAL \\ A Scientific Quarterly Refereed Journal Issued by Lebanese French University - Erbil, Kurdistan, Iraq \\ Vol. ( 3 ), Issue ( 4 ), Fall 2018 \\ ISSN 2518-6566 (Online) - ISSN 2518-6558 (Print)}

LF U

is not very unique and distinctive, it is refused to be given protection, particularly when it is used for packaging and surfaces of products. ${ }^{69}$

It has been evident that the availability of colour has been taken into account by the authorities when colour per se has been subject matter ${ }^{70}$ in order to enhance free competition. A general approach established in Libertel case is influenced by the fear of 'unjustified competitive advantages for a single trader'; as a result, only few applications of single colours have been successive - that is, the vast majority of them have been refused. ${ }^{71}$

The argument can be made that currently, there seems to be a further requirement for colour per se, namely the absence of 'unjustified competitive advantages'.$^{72}$ Further, as a general rule under TFEU ${ }^{73}$ article 102-106, any abuse to free competition is prohibited in the internal market. Thus, whenever IP rights, including trade mark ones and competition rules clash, the rules which protect competition will not only involve, but also will prevail; this has been reaffirmed by the ECJ as well. ${ }^{74}$ Trade mark law will not be applied in a vacuity rather it takes factual, market and business contexts, including those of competition into account. ${ }^{75}$ It would be said that the above-mentioned arguments focus their attention on free competition which should prevail whenever trade mark rights threaten it.

\section{Justifications for a Single Colour to be Trademarked}

On the other hand, there are arguments that justify allowing the registration of a single colour without giving too much attention to the idea of free competition or public interest. First, the Trade Marks Directive does not require that free competition should be taken into consideration. ${ }^{76}$ Further, it can be argued that competitors are not precluded by a trade mark and they are free to use identical products - that is, if they wish to compete, trade mark

\footnotetext{
69 Kudrjavceva (n 3) 42.

70 Sreepada (n 55) 1131.

${ }^{71}$ Kudrjavceva (n 3) 41.

72 ibid.

73 Treaty on the Functioning of the European Union.

74 Katerina Shaw, 'Likelihood of Coexistence a Comparative Analysis of the Interplay Between European Trademark Law and Free Competition' (2009) 18 U Balt Intell Prop L J 51.

75 Vlotina Liakatou and Spyros Maniati, 'Red soles, gas bottles and ethereal market places: competition, context and trade mark law' (2012) 34(1) EIPR 1.

76 Trade Marks Directive, Art. 3(3); also Art. 7(1)(b) does not require that.
} 


\section{QALAAI ZANIST SCIENTIFIC JOURNAL \\ A Scientific Quarterly Refereed Journal Issued by Lebanese French University - Erbil, Kurdistan, Iraq \\ Vol. ( 3 ), Issue ( 4 ), Fall 2018 \\ ISSN 2518-6566 (Online) - ISSN 2518-6558 (Print)}

LF U

imposes no restriction on them using the same goods and services. The only restriction is that other competitors cannot employ the same trade mark. ${ }^{77}$

It is further argued that, if allowing the registration of a trade mark is conditioned on satisfying a further requirement, namely absent of unfair competition, there will be extra requirement imposed upon colour mark only. This approach was taken in Light Green case, when it was stated that the necessity that there should be free availability of certain colours or their risk that they may grant monopolisation will not be taken into account; this is because there is not such a requirement under Art. 7(1)(b) of the CTMR. ${ }^{78}$

Moreover, some commentators have noted and argue that Article 102 of the TFEU, regarding trade marks has not played a great role in European jurisprudence; therefore, they have taken the view that trade mark law has its own safeguards against any abuse of market power and those safeguards are sufficient..$^{79}$ It is further argued that it is a dangerous tendency to rely extensively upon competition arguments since it may amount to the probability of not granting colour trade marks registration at all. Also, it would be unfair to deny protection to a colour mark (after having its distinctiveness through use) when the reason is lack of availability. ${ }^{80}$ Thus, there should not be too much attention paid to the issue of availability because first, there are plenty of colours available; secondly, there is already a limitation by the functionality rules upon the possibility of registration. ${ }^{81}$

It would therefore be said that trade marks must not be categorised on the basis of whether the consideration of public interest is to be taken into account as it is impossible to do so-that is, if a sign is distinctive through use, it must be deemed as a mark. ${ }^{82}$ This was established in Cadbury case. However, that was the only challenge by the English court and was a step forward;

\footnotetext{
77 Shaw (n 77) 51.

78 Decision of the Third Board of Appeal of [18 December 2000] in Case R 122/1998-3 (Light Green), para 10.

79 Shaw (n 77) 51.

${ }^{80}$ International Trademark Association, Board Resolutions, 'Protectability of Color Trademarks' 20 November 1996 http://www.inta.org/Advocacy/Pages/ProtectabilityofColorTrademarks.aspx > accessed

81 ibid. 3 July 2018.

82 Tanya Aplin and Jennifer Davis, Intellectual Property Law Texts, Cases, and Materials (1 $1^{\text {st }}$ edn, OUP 2009) 262.
} 


\section{QALAAI ZANIST SCIENTIFIC JOURNAL \\ A Scientific Quarterly Refereed Journal Issued by Lebanese French University - Erbil, Kurdistan, Iraq \\ Vol. ( 3 ), Issue ( 4 ), Fall 2018 \\ ISSN 2518-6566 (Online) - ISSN 2518-6558 (Print)}

LFU

therefore, there might be a need for further clarifications since further decisions and time will decide whether the Cadbury decision is a tendency for future.

\section{The Balance between Leaving Colours Free for Others to Use and Recognising Distinctiveness Acquired through Use}

Apparently, there is a sort of contradiction between, on the one hand, leaving marks free for others to use, and recognising distinctiveness through use on the other. Thus, both arguments and counters need to be reconciled since, on the one hand, trade marks, including colour per se grant their owners exclusive rights and prevent others from competing with trade mark ownersthat is, restricting their rights. Therefore, competition rules should limit these anti-competitive exercises. ${ }^{83}$ On the other hand, trade mark and competition laws may share certain goals such as promotion of innovations and commercial activities; therefore, competition may not be achieved without protection of intellectual property, ${ }^{84}$ including trade marks.

It is also argued that the English courts have also acknowledged that if marks are registered, it will grant a monopoly which is not only ant-competitive, but also might preclude others from using the marks which are in limited supply and socially useful. Thus, it has been noted that the ECJ has endeavoured to keep the balance between both trade mark competition rules. ${ }^{85}$ However, it has been evident that the ECJ does not take into account any consideration as long as the mark acquired distinctiveness through use; any mark is acting as a badge of origin is registered. ${ }^{86}$ Thus, a colour becomes distinctive through use (but not inherently), it will be registered.

A further interesting argument can be made is that colour per se may not be undesirable if it is given to certain businesses. Fashion industry may be a prime example. There would be various reasons that fashion can be granted with a single colour or a shade of colour per se such as Red Sole Mark. ${ }^{87}$ First, it is an objective of modern trademark law to grant protection to marks which act as

83 Olav Kolstad, 'Competition law and intellectual property rights - outline of an economic-based approach' in Josef Drexl (ed), Research handbook on intellectual property and competition law (Cheltenham Edward Elgar 2008) 3.

${ }^{84}$ Kudrjavceva (n 3) 41.

${ }^{85}$ Aplin and Davis (n 82) 262-3.

86 ibid 262.

87 Danielle E. Gorman, 'Protection Single Colour Trademarks in Fashion after Louboutin' (2012) 30 Cardozo Arts and Ent LJ 101. 


\section{QALAAI ZANIST SCIENTIFIC JOURNAL \\ A Scientific Quarterly Refereed Journal Issued by Lebanese French University - Erbil, Kurdistan, Iraq \\ Vol. ( 3 ), Issue ( 4 ), Fall 2018 \\ ISSN 2518-6566 (Online) - ISSN 2518-6558 (Print)}

LF U

identifiers; secondly, this allowance will fit within the 'expansion trajectory' of protection that the law may afford. Thirdly, it has been admitted that fashion has not been sufficiently protected by other IP rights. This would be an immediate first step towards the goal that fashion designers should be provided with having greater legal recourses. ${ }^{88}$

Form this argument, it can be asked whether a chocolate should also be granted protection by a single colour. The answer may not be straightforward as it was regarding fashion industries. This may be because there are other marks available for chocolate industry, for example.

The recent tendency is that without giving any attention, once a colour acquired distinctiveness, it must be granted protection providing that it has met all conditions required. It seems therefore that the idea of acquiring distinctiveness through use will be given priority over competition or any other arguments, as was seen in Cadbury case. This may simply because first, distinctiveness for colour per se may be much more difficult than that for traditional marks; secondly, because of the peculiarity and the nature which a colour has. ${ }^{89}$ Thirdly, it is a goal of a trade mark even if it contradicts competition rules. A further reason, there is no such a requirement (free competition or availability of colour consideration) to be fulfilled; finally, there are grounds for refusal-that is, it is undesirable when a colour is dealt with differently from other marks.

\section{Single Colour Registration under the Iraqi Law}

In Iraq, trade marks are dealt with under the Law of Trademarks and Descriptions No. 21 of $1957 .{ }^{90}$ However, after toppling down the Iraqi Regime in 2004, this law was significantly amended by the Coalition Provisional Authority. ${ }^{91}$ This is mainly due to the fact that Iraq needed to adopt a modern intellectual property system. Further, in 1975, Iraq ratified both the Paris Convention for the Protection of Industrial Property (1967 Act) and the World Intellectual Property

\footnotetext{
88 ibid.

89 Kudrjavceva (n 3) 23.

90 This Law was published in the Iraqi Official Gazette No.4003 on 16/06/1957. However, it was amended by the CPA Order No. 80 in 2004.

91 Coalition Provisional Authority Order Number 80, Amendments to the Trademarks and Descriptions Law No

21 of 1957, s 1(1). This was published in the Iraqi Official Gazette No.3983 in June 20014.
} 


\section{QALAAI ZANIST SCIENTIFIC JOURNAL \\ A Scientific Quarterly Refereed Journal Issued by Lebanese French University - Erbil, Kurdistan, Iraq \\ Vol. ( 3 ), Issue ( 4 ), Fall 2018 \\ ISSN 2518-6566 (Online) - ISSN 2518-6558 (Print)}

LF U

Organizations (WIPO) Convention, and in 1976, it became a member of the WIPO. This amendment also aims at complying the Iraqi law with the requirements of the TRIPS Convention in order to become permanent member of the WTO. ${ }^{92}$

The Iraqi Trademarks Descriptions Law did not define non-traditional marks, including colours and single colours, to be registered as trade marks, nor did it recognize them as it defined the defined a 'mark', in general, as any shape of words, signatures, figures, letters, design, symbols, addresses, seals, drawings, engravings or combinations, if used or intended to be used upon any goods or in connection therewith provided that it can distinguish the goods belong to the proprietor of such trademarks by virtue of manufacture, selection, dealing with or offering for sale. ${ }^{93}$

However, the amended law defines a trade mark as "Any sign, or any combination of signs, capable of distinguishing the goods of one undertaking from those of other undertakings, shall be capable of constituting a trademark. Such signs, in particular words including personal names, letters, numerals, figurative elements and colours as well as any combination of such signs, shall be eligible for registration as trademarks. Where signs are not inherently capable of distinguishing the relevant goods or services, registrability will depend on distinctiveness acquired through use. Signs need not be visually perceptible in order to be eligible for protection as trademarks." 94 This definition is taken out from the definition of a trade mark under the TRIPS Agreement. ${ }^{95}$

Therefore, it can be said that the intention of the Iraqi legislator is to broadly protect any mark as a trade mark after fulfilling all the requirements. ${ }^{96}$ However, registering a single colour as a trade mark may face the problem of distinctiveness character as proving inherent or acquired distinctiveness might

92 Rasha Al Ardah, 'Overview of the Trademarks Law in Iraq' (September 2012) Al-Tamimi \& Co <https://www.tamimi.com/law-update-articles/overview-of-the-trademarks-law-in-iraq/> accessed 12 July 2018.

${ }^{93}$ See Ahmed Aziz Hassan, 'An Investigation of the Non- Traditional Trade Marks under both the European Union and the United States of America Regimes- an Analysis in View of their Potential Introduction in the Kurdistan Region of Iraq' (Master Thesis, The University of Nottingham, 2013) for further information.

${ }^{94}$ Article (1) of the amended trade mark law No 21 of 1957.

95 TRIPS Agreement (n 15), s 2, art 15(1). <https://www.wto.org/english/docs e/legal e/27trips 04 e.htm> accessed 9 July 2018.

96 See Samiha Al-Qilyubi, 'Industrial Property' (Dar Alnahdha Alarabiyah, Cairo, 2005) 480-492 (in Arabic) for more information about the requirements and further reading. 


\section{QALAAI ZANIST SCIENTIFIC JOURNAL \\ A Scientific Quarterly Refereed Journal Issued by Lebanese French University - Erbil, Kurdistan, Iraq \\ Vol. ( 3 ), Issue ( 4 ), Fall 2018 \\ ISSN 2518-6566 (Online) - ISSN 2518-6558 (Print)}

LFU

of non-traditional marks is more difficult than the one of a traditional mark. Further, one may face the same problems as discussed above ${ }^{97}$ while registering a colour mark.

Some argue that the registration of a colour per se should not be allowed as it will hinder competition and will lead to monopolization. It is further argued that colour per se does not have distinctiveness character as a requirement for registration. However, a combination of two colours or more may have distinctiveness character; for example, the colours of the registered Signal 2 trademarked toothpaste which is a two-line red colour and a white line inside can be a distinctive mark. ${ }^{98}$

Although in the Kurdistan Region of Iraq, a single colour has not been registered as trade mark, ${ }^{99}$ the application for registration of a single colour (colour per se) can be an enquiry of a person in the future since the trademarks registrar has the discretionary power over the registration of such a mark. This is after the registrar has found that all the requirements are satisfied. It can, therefore, be said that the Iraqi law allows of registration of even a single colour.

If an application for a single colour is rejected, the applicant is entitled to challenge the decision before the court within 30 days from the date of the rejection notice receipt. ${ }^{100}$

\section{Conclusion}

This paper has discussed the title question and has shown that colour per se as any other mark should fulfil all-but not further-requirements in order for it to be registered. The arguments have shown against a colour to be trademarked and those in favour of a single colour to be registered. The former arguments are mainly the depletion theory and leaving colours available in the sake of free competition. However, the lather argues that whenever a mark, including a colour become distinctive through use, it is to be registered. This justification is in line with the Trade Marks Directive and Trade Mark law.

\footnotetext{
97 See above Requirements for Registration of a Trade Mark, page 5 of this paper.

98 Alsayid Abdulwahab Arfa, 'protection of the intellectual property rights' (Dar Almatbua'at Aljamiy'ah, Alexandria, 2004) 95 (in Arabic).

99 According to the search the author has done on the website of the Ministry of Trade and Industry, Directorate of Trademarks Registration, which has published all the registered trademarks in the (publications of trademarks and commercial data) $<$ http://www. mtikrg.org/Default.aspx?page =category \&c=hb $>$ accessed 13 July 2018.

${ }^{100}$ Article (10) of the the amended trade mark law No 21 of 1957.
} 
In principle, colour per se should be left free to the public unless a colour is acquired distinctiveness through use, and of course meets all conditions, then it should be protected, even if it falls under one of the categories of marks which ought to be left free for others to use. ${ }^{101}$ However, based on anything other than the commercial reputation of a product or service, or of its source, trademark rights are not supposed to interfere with competition. Facilitating the registration and protection of colour per se would lead to locking up the aesthetic and communicative attributes of a single colour by undertakings; thus, it would undermine legitimate competition. ${ }^{102}$

Between these two different poles, it could be said that allowing registration for colour per se might not stimulate competition, and, at the same time, may not undermine it since colour per se can distinguish goods of different competitors as identifiers; this would mean preventing unfair competition. ${ }^{103}$ Providing that colour per se has met all requirements, in particular acquiring distinctiveness through use rather than inherently; further, it is not merely a functional or basic colour. For instance, purple shade seems not to be functional as there may not be any relation between a Cadbury chocolate and colour purple. The focus would be on the investment, the use for a long time, advertising and other considerations when deciding whether colour per se should be registered. In other words, 'free competition should not be protected at the expense of a colour mark'. ${ }^{104}$

It might be argued that merely one case may not suffice to say that this is the English approach for a single colour; it could however be said that the English courts tend to choose this attitude-protecting a single colour-as an approach rather than to decline taking it. This may be because as was stated in Libertil case, the application might have been successfully accepted if internationally colour codes were used.

\footnotetext{
101 Aplin and Davis (n 82) 252.

102 Bartow (n 65) 263.

103 Sreepada (n 55) 1131.

104 Kudrjavceva (n 3) 58.
} 


\section{QALAAI ZANIST SCIENTIFIC JOURNAL}

A Scientific Quarterly Refereed Journal Iss ued by Lebanese French University - Erbil, Kurdistan, Iraq

LF U

Vol. ( 3 ), Issue ( 1 ), January 2018

ISSN 2518-6566 (Online) - ISSN 2518-6558 (Print)

\section{References}

\section{Legislation}

Agreement on Trade-Related Aspects of Intellectual Property Rights (1994)

Coalition Provisional Authority Order Number 80, Amendments to the Trademarks and Descriptions Law No 21 of 1957

Council Regulation (EC) No 207/2009 of 26 February 2009 on the Community trade mark [2009] L78/1

Directive 2008/95/EC of 22 October 2008 to approximate the laws of the Member States relating to trade marks [2008] L 299/25

Iraqi Trademarks and Descriptions No. 21 of 1957

Trade Marks Act 1994

Treaty on the Functioning of the European Union

TRIPS Agreement

\section{List of Cases}

BP Amoco plc v John Kelly Ltd [2002] FSR 4 and 5

Case C-104/01 Libertel Groep BV v Benelux-Merkenbureau [2003] I-3793 [2004] ECR II3843

Case C-273/00 Ralf Sieckmann v Deutsches Patent- und Markenamt ('Methylcinnamat'), [2002] ECR I-11737

Case C-321/03 Dyson Ltd. v. Registrar of Trade Marks [2007] ECR I-687, [2007] 2 CMLR 14, [2007] RPC 27

Case C-404/02 Nicholas PLC v. Registrar of Trade Marks [2004] ECR I-8499

Case T-173/00 KWS Saat AG v (OHIM) [2002] ECR II-3847, 25

Decision of the First Board of Appeal [1 July 2005] in Case $R$ 799/2004-1 (IKEA, Blue and Yellow)

Farbmarke Gelb-Schwarz, BGH GRUR 491, 30 IIC 809 (1999) - Farbmarke gelb/Schwarz Glaxo Group v. Dowelhurst Ltd [2004] FSR 52 


\section{QALAAI ZANIST SCIENTIFIC JOURNAL}

A Scientific Quarterly Refereed Journal Iss ued by Lebanese French University - Erbil, Kurdistan, Iraq

LF U

Vol. ( 3 ), Issue ( 1 ), January 2018

ISSN 2518-6566 (Online) - ISSN 2518-6558 (Print)

Philips Electronic BV v. Remington Consumer Products [1998] RPC 283, per Jacob J

Qualitex Co. v. Jacobson Prods. Co. case [1995] 514 US 159

Societe des Produits Nestle SA v Cadbury UK Ltd [2012] EWHC 2637 (Ch); [2013] E.T.M.R. 2 (Ch D)

The Third Board of Appeal's decision [12 February 1998] in (Orange case)

The Third Board of Appeal's decision [18 December 2000] in Case R 122/1998-3 (Light Green)

\section{Books}

Al-Qilyubi S, 'Industrial Property' (Dar Alnahdha Alarabiyah, Cairo, 2005) (in Arabic)

Aplin T and Davis J, Intellectual Property Law Texts, Cases, and Materials ( $1^{\text {st }}$ edn, OUP 2009)

Arfa A A, 'protection of the intellectual property rights' (Dar Almatbua'at Aljamiy'ah, Alexandria, 2004) (in Arabic)

Kolstad O, 'Competition law and intellectual property rights - outline of an economicbased approach' in Drexl J (ed), Research handbook on intellectual property and competition law (Cheltenham Edward Elgar 2008)

Torremans P, Holyak and Torremans intellectual property law (6th edn, OUP 2010)

\section{Journal Articles}

Bainbridge DI, 'Smell, sound, colour and shape trade marks: an unhappy flirtation?' (2004) JBL 219

Bartow A, 'the True Colors of Trademark Law: Green lighting a Red Tide of Anti Competition Blues' (2009) 207 Kentucky Law Journal 263

Caldarola MC, 'Questions relating to abstract colour trade marks: recent developments in Germany' (2003) 25(6) EIPR 248

Gorman DE, 'Protection Single Colour Trademarks in Fashion after Louboutin' (2012) 30 Cardozo Arts and Ent L 101 
Kudrjavceva J, 'Issues surrounding registration of colour trade marks' (2012) 09 Riga Graduate School of Law research paper 1

Liakatou V and Maniati S, 'Red soles, gas bottles and ethereal market places: competition, context and trade mark law' (2012) 34(1) EIPR 1

Obayuwana A, 'Unintentional trademark expansion and unfair competition in cyberspace: the domain name phenomenon' (2012) 34(3) EIPR 177

Schulze C, 'Registering colour trade marks in the European Union' (2003) 25(2) EIPR 55

Shaw K, 'Likelihood of Coexistence a Comparative Analysis of the Interplay Between European Trademark Law and Free Competition' (2009) 18 U Balt Intell Prop L J 51

Sreepada S, 'The New Black: Trademark Protection for Color Marks in the Fashion Industry' (2009) 19(4) Fordham Intellectual property, Media and Entertainment Law Journal 1131

Wood I and Bagnall M, 'Colour marks: a purple decision clears the way forward' (2013) 35(5) EIPR 300

\section{Online Materials}

AIPPI, Report of the UK Group, Q 181 by Jane Mutimear, Kathrin Vowinckel, Richard Abnett, 'Conditions for registration and scope of protection of non-conventional trademarks'

<http://www.aippi.org.uk/docs/Q181.UK\%20Group.Response.pdf> accessed 20 June 2018

Application no 2376879 by Cadbury Ltd and Opposition 97819 by Societe des Produits Nestlé S.A, see paras: 1, 9, 13, 103, 104, 16 and $111<$ http://www.ipo.gov.uk/types/tm/t-os/t-find/t-challenge-decisionresults/o35811.pdf> accessed 17 May 2018

Ardah R A, 'Overview of the Trademarks Law in Iraq' (September 2012) Al-Tamimi \&

Co <https://www.tamimi.com/law-update-articles/overview-of-the-trademarks-law-iniraq/> accessed 12 July 2018

International Trademark Association, Board Resolutions, 'Protectability of Color Trademarks' 


\section{<http://www.inta.org/Advocacy/Pages/ProtectabilityofColorTrademarks.aspx> accessed 3 July 2018}

Ministry of Trade and Industry, Directorate of Trademarks Registration, which has published all the registered trademarks in the (publications of trademarks and commercial data) <http://www.mtikrg.org/Default.aspx?page=category\&c=hb> accessed 13 July 2018

Morton J, 'Why Colour Matters' (2010) <http://www.colorcom.com/research/why-colormatters > accessed 25 July 2018

Office for the Harmonization in the Internal Market, CTM statistics on 03/04/2012, SSC009 p.

<http://oami.europa.eu/ows/rw/resource/documents/OHIM/statistics/ssc009statistics of community trade marks 2012.pdf> accessed 18 July 2018

\section{Unpublished Thesis}

Ahmed Aziz Hassan, 'An Investigation of the Non- Traditional Trade Marks under both the European Union and the United States of America Regimes- an Analysis in View of their Potential Introduction in the Kurdistan Region of Iraq' (Master Thesis, The University of Nottingham, 2013)

\section{يوخته}

نيشانه بازركانييه كان روّليّكى گرينگ له بازركانى كردن دهبينن جونكه وادهكهن بهكاربهر بتوانيت

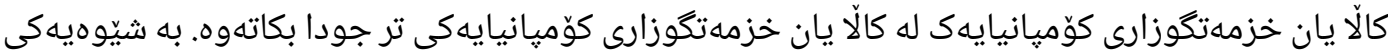
كثتى نيشانهى بازركانى لهسهر بهرههمهكه دادهنريَت بوّ ئهوهى بهكابهر به ئاسانى بتوانيّيت بهرههمهكه

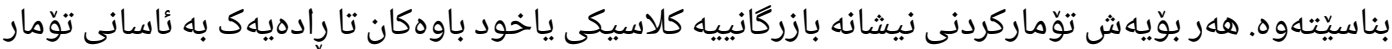

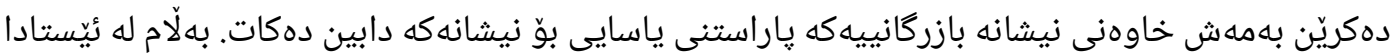

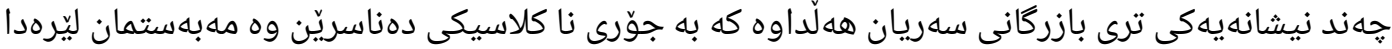

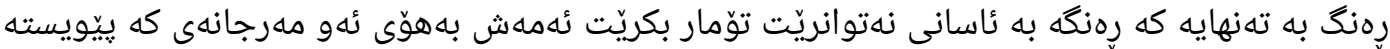

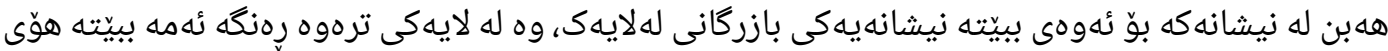

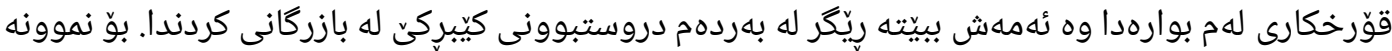




\section{QALAAI ZANIST SCIENTIFIC JOURNAL}

A Scientific Quarterly Refereed Journal Iss ued by Lebanese French University - Erbil, Kurdistan, Iraq

LF U

Vol. ( 3 ), Issue ( 1 ), January 2018

ISSN 2518-6566 (Online) - ISSN 2518-6558 (Print)

ئه گهر كهسيّك رِنكيّكى دياريكراو وهكو نيشانهى بازركانى توّمار بكات، ئهوا ئهو كهسه ههتا ههتايه دهبيّته

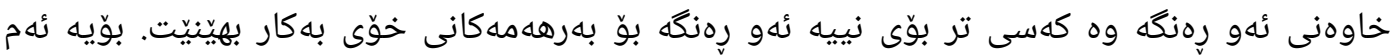

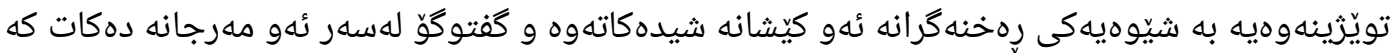

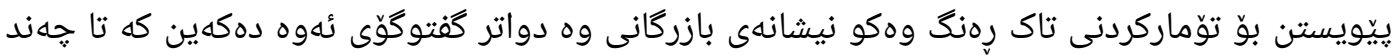

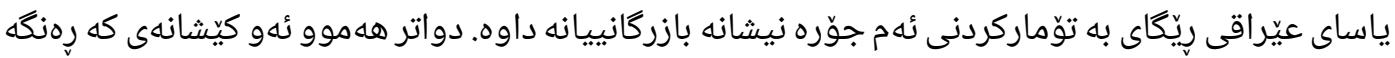

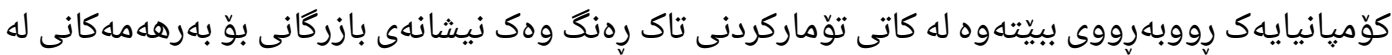
ههريمى كوردستان و له عيراق. 